\title{
Microbial Community Structure of Activated Sludge As Investigated With DGGE
}

\author{
Shah MP* \\ Division of Applied \& Environmental Microbiology, Enviro Technology Limited, Industrial Waste Water Research Laboratory, India
}

Received: 14 October, 2016; Accepted: 21 November, 2016; Published: 24 November, 2016

*Corresponding author: Shah MP, Division of Applied \& Environmental Microbiology, Enviro Technology Limited, Industrial Waste Water Research Laboratory, India, E-mail: shahmp@beil.co.in

\begin{abstract}
Microbial activity and structure of the bacterial community of activated sludge reactors, which treated industrial wastewater, were studied. Microbial communities, including ammonia oxidizing bacteria, Eubacterium and actinomycete communities were studied in two different systems with the polymerase chain electrophoresis gradient denaturing gel reaction using amplified gene fragments, $16 \mathrm{~S}$ rRNA of bacteria. Both systems, which used an anoxic-aerobic process and anaerobic-anoxic-aerobic process, respectively, received the same industrial wastewater, operating under the same conditions and showed similar processing performance. Oxidizing bacterial communities of ammonia from two systems showed almost identical structures corresponding to ammonia removal, while the actinomycete bacterial community showed obvious differences. FISH results showed that the ammonia-oxidizing bacterial cells in the anaerobic-anoxic-aerobic system increased by $3.8 \pm 0.2 \%$ of the total bacterial population, while those in the anoxic-aerobic system represented $1.7 \pm 0.2 \%$. Thus, the existence of an anaerobic-anoxic environment in the anaerobic-aerobic system resulted in a marked increase in biodiversity.
\end{abstract}

Keywords: Industrial waste water; 16S rRNA; Anoxic; Anaerobic; Aerobic; FISH

\section{Introduction}

The growth of the world population, the development of various industries, and the use of fertilizers and pesticides in modern agriculture has overloaded not only the water resources but also the atmosphere and the soil with pollutants [1]. The degradation of the environment due to the discharge of polluting wastewater from industrial sources is a real problem in a number of countries. This situation is even not as good as in developing countries like India where little or no treatment is carried out before the discharge [2]. Moter and Gobel developed the first activated sludge system for purification of wastewater in Manchester [3]. However, the role of microbial consortia in this process is still not completely understood. Culture-based techniques were found to be too selective to give a comprehensive and authentic picture of the entire microbial community as it has been estimated that the majority (over 99\%) of bacteria in nature cannot be cultivated by using traditional techniques [4]. Activated sludge is a very thorny system, comprised of a variety of populations including heterotrophic and autotrophic bacteria, fungi and protozoa [5]. The relationship between the microbial composition and the treatment performance of activated sludge processes has long attracted the attention of microbial ecologists and environmental engineers, as this information might be useful for the proper design and operation of biological wastewater treatment systems. Protozoa have been studied and utilized as an important indicator for judging process performance and effluent quality since the 1970 s, because these large sized microorganisms can be directly observed and identified under a microscope [6]. The development of DNA-based techniques has revolutionized the ability to characterize and identify the diversity and taxonomy of environmental organisms in a wide variety of niches [7,8], such as food [9], soil [10], water [11] and the human body [12]. A major advantage of this approach is that it allows monitoring, exposure and investigation of the genetic targets of interest directly from environmental samples, lacking the additional steps of cultivation and recovery $[13,14]$, which are known to be inefficient in recuperating symbiotic, facultative, stationary, slow growing, $\mathrm{pH}$ sensitive and various other fastidious microorganisms $[15,16]$. In spite of its attractiveness, many molecular studies applied to soil and water have indicated that the choice of processing method and the design of extraction protocols may affect the degree of lysis of the microorganisms present in the sample (and hence the recovery of their template DNA) [17], the integrity and size of DNA obtained [18] and the extent of co-extraction of both organic and inorganic impurities which may interfere with PCR amplification [19]. These factors may also affect the usefulness and applicability of the DNA for further molecular analysis [20] and drastically affect the recovery of molecular diversity, leading to mistakes in the interpretation of the true diversity and taxa present [21,22]. Despite the knowledge that microbial communities evolving in wastewater treatment plants contribute on handling processes, there are only a few reports concerning the study of bacterial communities [23]. Until now, studies were carried out using mainly traditional microbiological schemes. The emergence of molecular techniques allowed the conquering of the problems associated with culturedependent methods that lead to an underestimation of the true diversity. Molecular methods such as 16S rDNA clone libraries [24], ribosomal intergenic spacer analyses [25], 16S-restriction 
fragment length polymorphism [26], repetitive extragenic palindrome polymerase chain reaction [27] and Fluorescent In Situ Hybridization [FISH) [27) have already been applied to the study of wastewater-associated microbial communities. The combination of PCR amplification of 16S rRNA genes with Denaturing Gradient Gel Electrophoresis [DGGE] analysis has also provided a useful means to directly characterize bacterial populations within many samples. Polymerase chain reaction -denaturing gradient gel electrophoresis has been successfully used in many fields of microbial ecology to assess the diversity of microbial communities and to determine the community dynamics in response to environmental variations. Studies concerning bacterial diversity in waste waters using a DGGEbased approach have been performed for reactor systems [28] and activated sludge [28], revealing the presence of highly complex bacterial communities. However, petty work has been done in order to apply this methodology to assess the bacterial diversity in industrial wastewater where the organic matter degradation takes place. In the present study, microbial communities of two different systems, an anoxic-anaerobic-aerobic process and an anoxic-aerobic process, respectively, receiving identical sewage and having similar treatment performance, were determined using group- specific PCR-DGGE and subsequent sequence analysis of rRNA genes. The community diversity of eubacteria and ammonia oxidizing bacteria, were investigated in the two systems to evaluate the effects of different designs on microbial populations. FISH was used for the determination of the ratio of ammonia oxidizing bacteria in each system with a probe.

\section{Materials \& Methods \\ DNA Isolation from samples of activated sludge}

Activated sludge samples were collected from the biological system of the industrial treatment plant, pelleted by centrifugation $\left(5000 \mathrm{xg}, 10 \mathrm{~min}, 4^{\circ} \mathrm{C}\right)$ and stored at $-45^{\circ} \mathrm{C}$ until isolation of DNA. Total genomic DNA was extracted from $0.3 \mathrm{~g}$ of activated sludge samples according to the mechanical method [6]. The samples were washed three times with $1 \times$ PBS buffer and disrupted with bead beating in lysis buffer [Tris-HCl $100 \mathrm{mM}, 100 \mathrm{mM}$ EDTA, $1.5 \mathrm{M} \mathrm{NaCl} ; \mathrm{pH}=8.0$ ). The samples were incubated 20 minutes at 1400 revolutions per minute and 200 ul of $10 \%$ SDS was added. After 30 minutes incubation at $65^{\circ} \mathrm{C}$ the samples were centrifuged twice at 13,000 rpm and placed on spin filters. DNA fixed on the filter was washed twice with a solution A1. The amount of DNA was measured spectrophotometrically, using qubit and stored at $-20^{\circ} \mathrm{C}$ until PCR amplification.

\section{Chemical analysis}

Water temperature and dissolved oxygen were determined in situ with a WTW model 330i/ SET and a model WTW OXI 96 respectively. Influent characteristics, namely the biochemical oxygen demand, chemical oxygen demand, suspended solids and $\mathrm{pH}$ were determined by standard methods [29] and portrayed in Table 1.

\section{Analysis of microbial community diversity by means of 16S rRNA using PCR-DGGE}

The DNA of the bulk community was extracted from 1.0 $\mathrm{mL}$ of sludge using a Fast DNA Spin Kit for Soil. The extracted
DNA was then subjected to PCR touchdown, using primers $341 \mathrm{~F}$ and $534 \mathrm{R}$ [30]. The primer $341 \mathrm{~F}$ contained a $44 \mathrm{bp}$ GC clamp. Amplification was performed in a thermal cycler. PCR products were separated using a code-D and $1 \mathrm{~mm}$ thick polyacrylamide gel system containing $8 \%(\mathrm{w} / \mathrm{v})$ acrylamide-bisacrylamide (37.5:1), TAE IX buffer, and a denaturing gradient of $30 \%$ to $70 \%$ (v/ v). Electrophoresis was performed in TAE buffer at $60^{\circ} \mathrm{C}$ and constant voltage for 14 hours. Gels were stained with 1:10 000 (v/ v) SYBR Green I and photographed using Gel Doc 2000 equipped with MULTIANALYST software. The central parts of DGGE bands were excised with a razor blade and soaked overnight in purified water. A portion of this ( $10 \mathrm{ul}$ ) was then removed and reamplified as described above. The re-amplified DNA fragments from the DGGE bands were sequenced directly or cloned into the pGEM-T Easy vector system prior to sequencing. The sequences were checked for possible chimeras using CHIMERA_CHECK program on the website of ribosomal database project. To determine the phylogenetic position of microorganisms detected in DGGE, the sequences of 16S rRNA genes analyzed were compared with databases of sequences available via BLAST search. The band patterns and intensities of the scanner gels were analyzed using Gel Compar software. After applying subtraction drive working capital, an analysis of each channel, acquiring densitometric curves was carried out by the software. A DNA band was identified if the tape represented more than $1.0 \%$ of the total intensity channel. A matrix was then constructed using this information, and has been used to calculate a set of digital values to describe the diversity of bacterial communities. As a parameter to the structural diversity of the microbial community, the Shannon index [31] of overall diversity, H, was calculated with the following formula: $\mathrm{H}=-\Sigma \mathrm{Pi} \bullet \ln (\mathrm{Pi})$ wherein $\mathrm{Pi}$ is the probability that major bands in a track: $\mathrm{H}$ was calculated on the basis of the bands on the gel lanes, using the intensities of the bands after the peak heights in the densitometric curve. The probability of material, $\mathrm{Pi}, \mathrm{Pi}$ was calculated as $=\mathrm{ni} / \mathrm{N}$, where ni is the height of the peak $\mathrm{i}$, and $\mathrm{N}$ is the sum of all peak heights in the densitometric curve. For the analysis of ammonia-oxidizing bacteria and activated sludge actinomycete populations, a nested PCR technique was used to increase the sensitivity [37]. In the first round, $1 \mu \mathrm{L}$ of the extracted DNA was added to Mastermix PCR and different primers were used, each with their own corresponding PCR protocol. During the second round of PCR, $1 \mu \mathrm{L}$ amplified product in the first round was added to $49 \mathrm{ul}$ of PCR mixture and then reamplified using their own protocol and corresponding PCR primers shown in Table 2.

\begin{tabular}{|l|l|l|l|l|l|l|}
\hline \multicolumn{7}{|l|}{ Table 1: Influent and effluent characteristics } \\
\hline Type & $\begin{array}{l}\text { CODCr } \\
\text { (mg/ l) }\end{array}$ & $\begin{array}{l}\text { BOD (mg/ } \\
\mathbf{l})\end{array}$ & $\begin{array}{l}\text { NH4 } \\
\text { (mg/ })\end{array}$ & $\begin{array}{l}\text { TN } \\
\text { (mg/ l) }\end{array}$ & $\begin{array}{l}\text { TP } \\
\text { (mg/ l) }\end{array}$ & $\begin{array}{l}\text { SS } \\
\text { (mg/ l) }\end{array}$ \\
\hline $\begin{array}{l}\text { Raw } \\
\text { Sewage }\end{array}$ & $450-800$ & $250-400$ & $35.6-47.5$ & $52-68$ & $49.0-62.0$ & $5.2-6.6$ \\
\hline $\begin{array}{l}\mathrm{A}_{2} \mathrm{O} \\
\text { effluent }\end{array}$ & $38.6-48.8$ & $12.4-18.6$ & $11.0-25.0$ & $38-44$ & $36.0-41.0$ & $0.6-3.8$ \\
\hline $\begin{array}{l}\text { AO } \\
\text { effluent }\end{array}$ & $32.4-40.2$ & $10.12-14.84$ & $8.6-17.8$ & $9.4-18.2$ & $33.6-38.5$ & $5.3-5.9$ \\
\hline
\end{tabular}




\section{Sequence Analysis of denaturing gradient gel electrophoresis Profiles}

The denaturing electrophoresis gel gradient profiles were analyzed with the fingerprint software database TM diversity. On the basis of the presence [1] or absence (0) of individual bands in each lane, a binary matrix was constructed. Binary data representing the banding patterns were used to generate a Dice pair wise distance matrix. A dendrogram was obtained by unweighted pair group analysis of the mean of the cluster means. The distance matrix was also used for the construction of a multiscale diagram scaling, on a two dimensional plane with artificial $\mathrm{x}$ - and $\mathrm{y}$-axis where each denaturing gradient electrophoresis gel fingerprint is placed at a certain time, so that similar samples are represented together. Clustering analysis and MDS were performed using the software Primer 5 [32]. Denaturing gradient electrophoresis gel patterns were also examined using two indices to field many aspects of microbial diversity. The ShannonWeaver index of diversity, $\mathrm{H}$ [33] and the index of equitability, E [34] were calculated for each sample as follows:

$$
\begin{aligned}
& H=-\sum\left(n_{i} / N\right) \log \left(\left(n_{i} / N\right),\right. \\
& E=H / \log S,
\end{aligned}
$$

Where, ni is the intensity of the relative area of each band electrophoresis denaturing gradient gel, $\mathrm{S}$ is the number of bands in denaturing gradient electrophoresis gel and $\mathrm{N}$ is the sum of all surfaces of all bands in a given sample [35]. The statistical significance of the variance in the index was assessed by a twoway analysis of variance. A canonical correspondence analysis was used to determine the multiple relationships between each variant denaturing gradient gel electrophoresis banding patterns and environmental parameters. The analysis was performed using CANOCO for Windows Version 4.5 [36] and its significance was evaluated by the Monte Carlo test with 1000 permutations.

\section{GC-MS analysis}

The Gas Chromatograph - Mass Spectrometry (GC-MS) analysis was performed by a MP5890GC/ MS. Chromatography was conditioned as follows: SE- 54 capillary column $(25 \mathrm{~m} \times$ $0.32 \mathrm{~mm}$ ); the column temperature was maintained at $40^{\circ} \mathrm{C}$ for 2 minutes, then heated to $250^{\circ} \mathrm{C}$, with an increment of $3 \sim 5^{\circ}$ $\mathrm{C} / \mathrm{min}$ and held at $250^{\circ} \mathrm{C}$ for $30 \mathrm{~min}$. Mass conditions were as follow: temperature of the MS ion source was $250^{\circ} \mathrm{C}$; the voltage multiplier is $2400 \mathrm{~V}$; the electron energy is $70 \mathrm{eV}$.

\section{Fluorescence in situ hybridization analysis}

Prior to hybridization, the samples were dispersed into single cells by sonication, and then treated immediately and fixed in $4 \%$ paraformaldehyde for 3 hours at $4^{\circ} \mathrm{C}$. After that, the biomass was washed with phosphate buffered saline $(\mathrm{pH} 7.4)$ and stored at a $1: 1$ ratio of phosphate buffered saline and $100 \%$ ethanol at $0^{\circ}$ $20^{\circ} \mathrm{C}$. All Hybridizations were performed at $46^{\circ} \mathrm{C}$ for $120 \mathrm{~min}$ as described by Manz, et al. (1992). The oligonucleotide probes of the 16S rRNA target - and the stringency used in this study are listed in Table 3.

After hybridization, the slides were mounted with Citifluor prevent money laundering and examined with an epi-fluorescence microscope Axio skop 2. All processing and image analysis were performed with the standard software provided by Zeiss. Three probes are listed in Table 3.

\section{Results}

\section{Physico-chemical characterization}

Sampling in the industrial wastewater treatment plant was done from two biological systems of aeration tanks. Influent physical and chemical characteristics during the sampling period are shown in Figure 1. Parameters such as biochemical oxygen demand, chemical oxygen demand and total suspended solids showed a high variation with pronounced peaks. The $\mathrm{pH}$ ranged from 6.7 to 7.6. Water temperature and DO concentration values registered in both systems were also rather unstable, with temperatures ranging from 11.3 to $29.7^{\circ} \mathrm{C}$ and DO varying between 0.10 and $3.14 \mathrm{mg} / \mathrm{l}$ (Figure 1).

\section{Bacterial community analysis using $16 \mathrm{~S}$ rRNA gene PCR-DGGE}

To follow the evolution of the microbial community during operation of the reactor, $16 \mathrm{~S}$ rRNA PCR amplified gene fragments were analyzed using DGGE (Figure 2). DGGE profiles show changes in the microbial population due to progressive reductions in HRT. The average band number per lane in each reactor used for diversity analysis was 19.7 (from 17 to 22) Al, 18.8 (from 15 to 22) in the A- II and 19.7 (from 17-22) in AI + II. The number and thickness of the bands observed in the DGGE profiles provide an estimate of species richness. The Shannon diversity index, $\mathrm{H}$,

\begin{tabular}{|c|c|c|c|c|c|c|c|c|}
\hline \multicolumn{9}{|c|}{ Table 2: PCR Primers used in this study } \\
\hline \multirow{3}{*}{ Primers } & \multirow{3}{*}{$\begin{array}{l}\text { Number } \\
\text { of cycles }\end{array}$} & \multicolumn{6}{|c|}{ PCR conditions } & \multirow{3}{*}{ References } \\
\hline & & \multicolumn{2}{|c|}{ Denaturation } & \multicolumn{2}{|c|}{ Annealing } & \multicolumn{2}{|c|}{ Elongation } & \\
\hline & & ${ }^{\circ} \mathrm{C}$ & $\min$ & ${ }^{\circ} \mathrm{C}$ & $\min$ & ${ }^{\circ} \mathrm{C}$ & $\min$ & \\
\hline $\begin{array}{l}\text { F243, } \\
\text { R1378r }\end{array}$ & 35 & 95 & 1 & 63 & 1 & 72 & 2 & [38] \\
\hline $\begin{array}{l}\text { CT0189fAB, } \\
\text { CT0189Fc, } \\
\text { CT0654r }\end{array}$ & 35 & 95 & 1 & 57 & 1 & 72 & 2 & [38] \\
\hline $\begin{array}{l}\text { GC-P338f, } \\
\text { P518r }\end{array}$ & 30 & 95 & 1 & 55 & 1 & 72 & 2 & [38] \\
\hline
\end{tabular}
from the DGGE band pattern of each sample was calculated to

Table 3: Analysis of wastewater components

\begin{tabular}{|l|c|c|c|c|c|c|}
\hline Sample & Hydrocarbons & $\begin{array}{c}\text { Alcoholic } \\
\text { aldehydes } \\
\text { and } \\
\text { ketone } \\
\text { acids }\end{array}$ & $\begin{array}{c}\text { Aromatic } \\
\text { hydrocarbons }\end{array}$ & Phenols & $\begin{array}{c}\text { Halogenated } \\
\text { hydrocarbons }\end{array}$ & Others \\
\hline Influent & 40 & 25 & 16 & 1 & 4 & 25 \\
\hline A-I & 58 & 28 & 16 & 4 & 18 & 58 \\
\hline A-II & 48 & 18 & 22 & 2 & 12 & 10 \\
\hline A-I+II & 52 & 26 & 20 & 3 & 15 & 14 \\
\hline
\end{tabular}


determine the diversity of the microbial community. Figure 3 shows changes in the Shannon diversity index $\mathrm{H}$, occurring at the same time than changes in HRT. After HRT reduction of 48 to 24 $\mathrm{h}$, the values of $\mathrm{H}$ in A-I and A-II increased slightly (2.80 and 2.63, respectively). At HRT $12 \mathrm{~h}$, microbial diversity recovered slightly in A-I. The final reduction of HRT decreased to $6 \mathrm{~h} \mathrm{H}$ for the three reactors. 16S rRNA gene sequences of 28 major groups ( 9 to A-I bands, 10 bands to A-II and A-9 bands I + II). Most of the sequences were found to be clustered in the Proteobacteria (17 bands) and Bacteroidetes ( 6 bands). The other band sequences were found to be clustered in the Actinobacteria (2 strips), phylum TM7 (2 bands) and Acidobacteria (1 band). In the Proteobacteria, most sequences were combined in the $\beta$-Proteobacteria, in particular in the control Burkholderiales (10 bands). In A-I, bands F4, F5 and F7 were present in all periods of operation and have become widespread as HRT has been reduced. F1, F2, F3 made minor bands, but was observed in almost all periods. $\mathrm{F} 6$ became widespread on days 40 and 46 (6 pm HRT).

In A-II, the profile does not change significantly during days 15-30 (HRT of $24 \mathrm{~h}$ and $12 \mathrm{~h}$ ) or days (40-50 HRT of 6 hours). Major groups, including Z3, Z4 and Z8, who were present during long periods (HRT of $24 \mathrm{~h}$ and $48 \mathrm{~h}$ ) persisted, but became minor after 30 days (HRT $12 \mathrm{~h}$ ). Z6, Z7 and Z9 have become large groups after 40 days (HRT) $6 \mathrm{~h}$ of operation. In A-I + II, Group N4, which is a minor component of the community during the first period, gradually became dominant after the operation of the
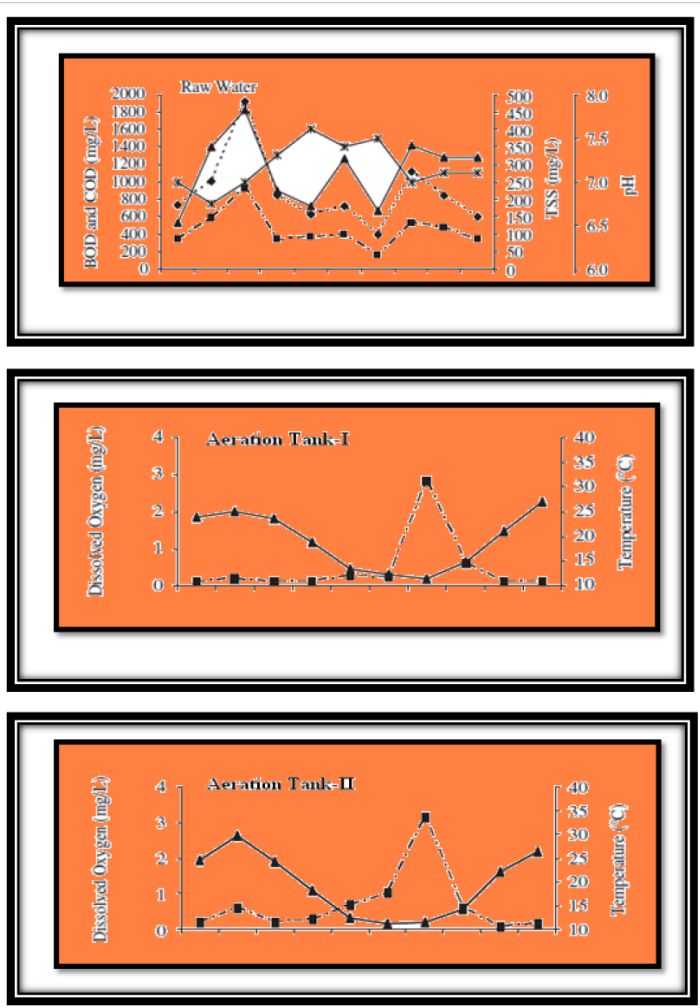

Figure 1: Waste water treatment systems operations conditions \& performance (a) BOD ( $\mathbf{\square})$, COD $(\bullet)$, TSS $(\boldsymbol{\Delta}), \mathrm{pH}(*)$ in raw water ; (b) temperature $(\boldsymbol{\Delta})$, Dissolved oxygen ( $\mathbf{\square})$

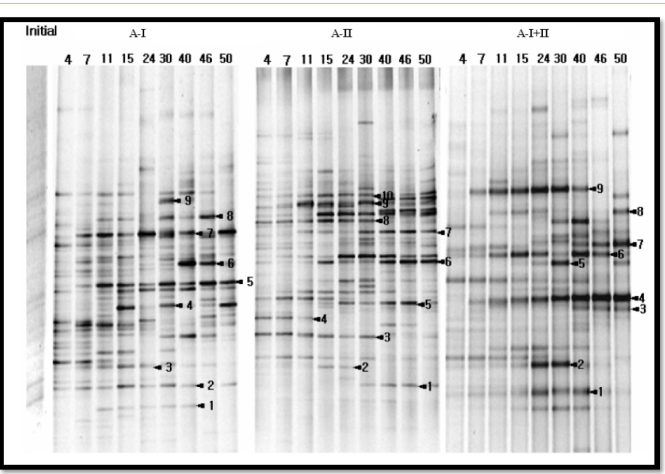

Figure 2: Denaturing gradient gel electrophoresis profiles of 16S rRNA gene of bacterial communities.

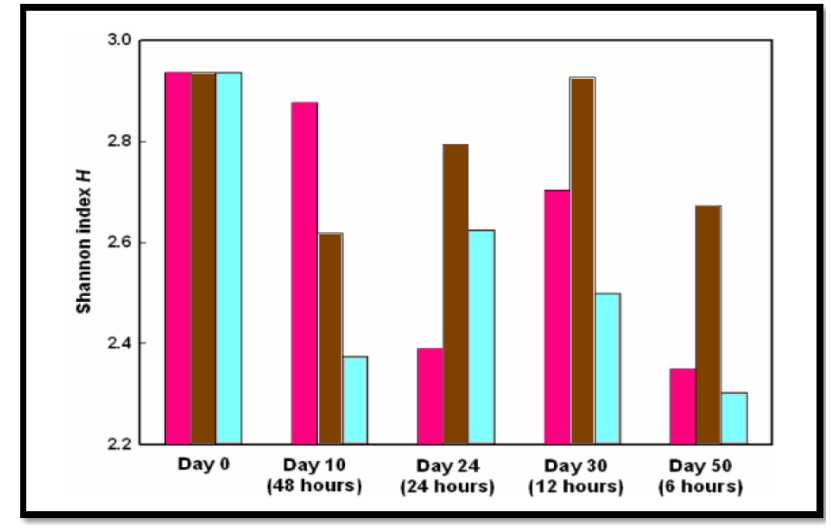

Figure 3: Change of Shannon index values throughout reactor operation (घ: A-I ; $\square$ A II; $\square: A-I-I I)$ Shannon index values (H) were calculated on the basis of the number and intensity of bands on the gel tracks. HRT is indicated in parenthesis.

reactor supported (with decreasing HRT). N1, N2, N5, N6 and N9 became dominant between days 15 and 40. Finally, days 40-50, new groups such as N7 and N8 became dominant. Only a limited number of bands with greater than $98 \%$ similarity with each other were recovered from sludge from all three aeration tanks. One contained F3, Z2, and N2, which are associated with Zoogloea, and the other contained F6, Z6, and N5, which are associated with Acidovorax. Sludge A-I and A-II had two sequences in common: F2 and Z1, which were associated with Microbacterium, and the other contained F9 and Z10, which were associated with the TM7 branch. These results demonstrate that the bacterial community is significantly different between the reactors, depending on the type of cyanide used.

\section{GC-MS analysis}

Analysis of samples in different places of the aeration tank was performed. Total ion chromatograms are shown in Figure 4. It showed that the type and amount of organic matter in wastewater have a decreasing trend in the flow direction. A-I + II, the areas of ICT crest of the wave were almost the same. This demonstrates that the disposal capacities in the last three organic compartments were extremely limited and most organics were removed in A-I and A-II. Further analysis of the types and relative 
amounts of the organic phases are illustrated in Table 3. It was shown that there were seven major types of organic matter in the influent. The number of organic matter in the influent was 112 and increased to 185 after the influent mixed with the return sludge in A-I. Then the number fell by 113 and 48, but rose again to 116 in the secondary settling tank. The number of organic matter in the secondary settling tank was close to that of the tributary. Thus, along the direction of flow of water, types of organic materials initially increased and then gradually decreased, and finally increased sharply. The sudden increase in substances was mainly those refractory organic as alcoholic aldehyde, ketone acid, hydrocarbons and halogenated hydrocarbons. It was deduced that these refractory organics were initially adsorbed by the activated sludge in an aeration condition. And in anoxic conditions of the secondary settling tank, the activity of aerobic bacteria and Zoogloea significantly reduced.

\section{FISH analysis}

In this investigation, several probes were used for the analysis of ammonia oxidizing bacteria in both systems. Probes $\beta$-A0233, Nsp436 and Nmo254 were respectively used for the detection of bacteria belonging to Nitrosospira cluster, and the cluster Nitrosomonas halophilic and halo tolerant, and total ammonia oxidizing bacteria (Table 4). It was found that in both systems, the genus Nitrosomonas shows about $1.8 \%$ (the system A20) and $1.6 \%$ (A0 system) respectively. The Nitrosospira proportions in the two systems were $2.2 \%$ (the system A20) and $1.2 \%$ (AO system), respectively. Hybridizations with Nmo254 probe showed that the total number of ammonia oxidizing bacteria in the system represented A20 average $3.6 \pm 0.2 \%$ of the total bacterial population while the AO system was only $1.9 \pm 0.2 \%$.

\section{Discussion}

This study was undertaken to promote our knowledge of

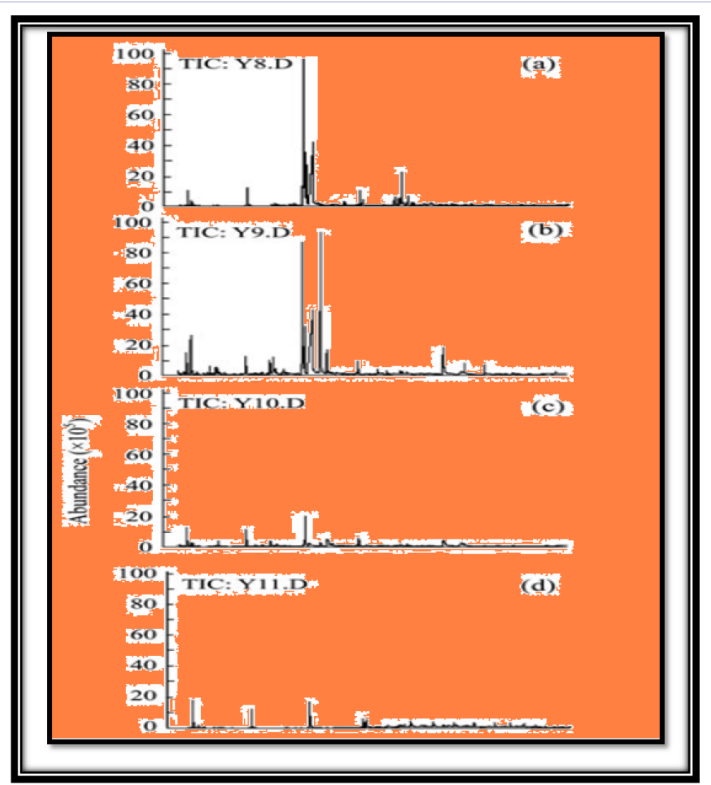

Figure 4: Chromatogram of (a) Influent (b) A-I (c) A-II (d) A-I+II
Table 4: Oligonucleotide Probes used in this study

\begin{tabular}{|l|l|l|}
\hline Probe & Sequence (59-39) & Target group \\
\hline b-A0233 & AGCTAATCAGRCATCGG & $\begin{array}{l}\text { All b-subgroup ammonia } \\
\text { oxidizers }\end{array}$ \\
\hline Nsp436 & TTTCGTTCCGGCTGAAAG & All Nitrosospira spp. \\
\hline Nmo254 & GTAGGCCSTTACCCYACC & All Nitrosomonas spp. \\
\hline
\end{tabular}

how microbial communities in wastewater are important in governing the settlement patterns of the bacterial community. An excellent strategy to assess these patterns is ensured by bacterial inoculation experiments. Microbial communities, obtained by activated sleds, are added to the pre-sterilized effluent selected and the implementation of certain community structures is compared. This study provides data that support an analysis of the foundations of the creation of the bacterial community. The study of the composition, structure and dynamics of microbial communities in aerated lagoons is essential to understand and ensure the proper functioning of the treatment system, a valuable tool for improving the design of aerated ponds. Since the ecological function of microorganisms depended on its community structure, operational performance and degrading treatment system efficiency could be reflected by changes in the microbial community structure. Each agency has its inherent niche and optimal substrates, and the microbial community would adjust its structure in response to the changing environment. Whereas little information is available on microbial communities that inhabit these ecosystems, the approach based on PCR-DGGE, which was applied here, has shown to be effective in obtaining new data on the structure and dynamics of these communities. In addition, the constant changes in DO concentration, the dramatic reduction of biodegradability and recycling of sludge also contributed to the constant changes in environmental conditions, which led to repetitive structural changes in bacterial community. As shown in Table 1, both systems show nearly identical performance in the removal of chemical oxygen demand, biochemical oxygen demand and suspended solids, while the anoxic-aerobic system had a slightly higher removal of ammonia and the anaerobicanoxic-aerobic system had a higher phosphate removal.

Although wastewater systems received identical, despite fairly similar constitutions, operating conditions, and treatment performance, both systems have shown quite different structures of microbial communities, except for ammonia oxidizing bacteria. It is interesting to note that the anoxic-aerobic-anaerobic system had far richer compositions of bacterial populations, actinomycetes and yeast. The richest community structures of these populations have been clearly linked to the creation of the anaerobic compartment. Most species that increased in the anoxic-anaerobic-aerobic system are perhaps those that tend to thrive in anaerobic environments. Temperature, DO and $\mathrm{pH}$ were the parameters that have shown to exert more influence on DGGE profiles. Yuz, et al. [23] previously reported temperature and DO as decisive parameters that affect community structure. Gilbride and colleagues [28] also found a significant correlation between the temperature and the structure of the bacterial communities of the activated sludge, as well as other influential 
parameters, such as COD and BOD, which showed no significant correlation. Table 1 indicates that the AO system has almost no phosphate removal capability. The A20 system, on the other hand, had shrinkage in TP of about $50 \%$, which can be attributed to the possible accumulation of ODP. The results of bacterial DGGE bands sequencing indicated that the dominant population that appear only in the A2O system belongs to the gamma Proteobacteria. Gamma proteobacteria are related to the elimination of phosphates [41]. To stabilize the structure of the bacterial community and the purification efficiency for industrial wastewater process $\mathrm{A} / \mathrm{O}$, the following strategies can be considered: (a) to strengthen the pre-treatment units to reduce the fluctuation of the waste water and avoiding shock loads to the activated sludge system; (b) transforming the original 03 compartment in the anoxic tank and packed compartment A/ $\mathrm{S}$ with the immobilized carriers in different places. Thus, after most of the organic materials responsible for the aerobic bacteria are depleted, anaerobic bacteria and facultative bacteria could become dominant for the degradation of pollutants by the alteration of the oxygen concentration. The relatively low removal of TP in the A20 system, on the other hand, might be related to the relatively high residual nitrate from the anoxic compartment. By this biodegradation step by step, the diversity of the microbial population and the stability of the community structure would be improved. The nitrate concentration of the mixed liquor in the anoxic compartment was as high as $12.4 \mathrm{mg} / \mathrm{L}$, which could be used as sufficient electron acceptors for the denitrifying bacteria that use organic substrates. Activated sludge actinomycetes have recently become the research focus because they are believed to play an important role in sludge bulking and foaming in activated sludge plants [43]. Competition between PAO and denitrifying bacteria for organic compounds could be the main reason for the weak removal of TP [42]. Microorganisms in different biological compartments would view its unique functions and the removal efficiency of pollutants will be improved. The average of the two IVR systems was $150 \mathrm{l} / \mathrm{g}$ (A20) and $100 \mathrm{l} / \mathrm{g}$ (AO) respectively. Aside from these negative roles, actinomycetes are active in the decomposition of organic matter. The diversity of actinomycetes in both systems suggests that some actinomycetes could also play an important role in the elimination of the organic substances. Further investigation, however, is needed to draw a final conclusion. High temperatures and low DO levels with the presence of microorganisms previously associated with anaerobic ecosystems found in this study, may explain the reduced efficacy of treatment. We hypothesize that the increase of the temperature and the depletion of DO levels create anoxic micro niches, promoting the growth of anaerobic bacteria, such as sulfate-reducing bacteria [44]. Among the four populations analyzed, only ammonia oxidizing bacterial communities have demonstrated a clear similarity $(77.5 \%)$ between the two processes, suggesting that the introduction of anaerobic compartment has not changed the wealth of AOB populations significantly. However, when analyzing the DGGE data from complex environmental samples through several related to DNA extraction and purification methods [45], the relative efficiency of gene amplification [46] or the PCR inhibition due to the presence of humic acids and heavy metals [47], or the impact of artifact bands due to excessive cycles of amplification should be taken into account. Nevertheless, analysis of bands DGGE profiles focuses on the numerical analysis of ability to be applied to the results obtained by molecular techniques. However, as shown by the results of FISH analysis, the proportion of the total AOB bacterial numbers in the two systems was very different [3.6 $\pm 0.2 \%$ for the system $\mathrm{A} 20$ and $1.9 \pm 0.2 \%$ for the $\mathrm{AO}$ system). Obviously, the A2O system had many more cells than AOB in the AO system. A previous study [48] demonstrated that sludge retention time mainly influenced the total AOBs in activated sludge systems. But in this study, the two systems had similar SRT and MLSS. Further studies are necessary in order to explain this phenomenon completely.

\section{References}

1. Maulin P Shah, Patel KA, Nair SS, Darji AM, Shaktisinh Maharaul. Optimization of Environmental Parameters on Decolorization of Remazol Black B Using Mixed Culture. American Journal of Microbiological Research. 2013;1(3):53-56.

2. Maulin P Shah. Microbial Degradation of Azo Dye by Pseudomonas spp. MPS-2 by an Application of Sequential Microaerophilic and Aerobic Process. American Journal of Microbiological Research. 2013;43:105112

3. Moter Annette, Gobel Ulf B. Fluorescence in situ hybridization (FISH) for direct visualization of microorganisms. Journal of Microbiological Methods. J Microbiol Methods. 2000;41(2):85-112.

4. Rondon Michele R, August Paul R, Bettermann Alan D, Brady Sean F, Grossmann Trudy H, Liles Mark R et al. Cloning the soil metagenome: a strategy for accessing the genetic and functional diversity of uncultured microorganisms. Applied and Environmental Microbiology. 2000;[6]66:2541-2547.

5. Madoni P, Davol D, Gibin G. Survey of filamentous microorganisms from bulking and foaming activated-sludge plants in Italy. Water Res. 2000;34(6):1767-1772.

6. Chen S, Xu M, Cao H. the activated-sludge fauna and performance of five sewage treatment plants in Beijing China. Eur J Protistol(2004);40(2) 30:147-152.

7. Nocker A, Burr M, Camper AK. Genotypic microbial community profiling: a critical technical review. Microb Ecol. 2007;54(2):276-89.

8. Holben, W.E ,Harris. D. DNA-based monitoring of total bacterial community structure in environmental samples Mol Ecol. 1995;4(5):627-31.

9. Giraffa G, Neviani E. DNA-based, culture-independent strategies for evaluating microbial communities in food-associated ecosystems. Int J Food Microbiol. 2001;67(1-2):19-34.

10. Ranjard L, Poly F, Nazaret S. Monitoring complex bacterial communities using culture-independent molecular techniques: application to soil environment. Res. Microbiol. 2000;151(3):167-177.

11. Kawai M, Matsutera E, Kanda H, Yamaguchi N, Tani K, Nasu M. 16S ribosomal DNA-based analysis of bacterial diversity in purified water used in pharmaceutical manufacturing processes by PCR and denaturing gradient gel electrophoresis. Appl Environ Microbiol. 2002;68(2):699-704.

12.Zhou X, Bent SJ, Schneider MG, Davis CC, Islam MR, Forney LJ. Characterizationof vaginal microbial communities in adult healthy women using cultivation-independent methods. Microbiology. 2004;150(Pt 8):2565-73. doi: 10.1099/mic.0.26905-0. 
13. Amann RI, Ludwig W, Schleifer KH. Phylogenetic identification and in situ detection of individual microbial cells without cultivation. Microbiol Rev. 1995;59(1):143-69.

14. Dahllöf I. Molecular community analysis of microbial diversity. Curr Opin Biotechnol. 2002;13(3):213-7.

15. Colwell R, Grimes J. Semantics and strategies. In Non-culturable Microorganisms in the Environment; Colwell R, Grimes J. Eds. ASM: Washington. DC, USA, 2000;1-5.

16. Kazuhiro K. Nonculturable bacterial populations that control environmental processes. Biosci. Ind. 1999;57:731-736.

17. Frostegard A, Courtois S, Ramisse V, Clerc S, Bernillon D, Le Gall F, et al. Quantification of bias related to the extraction of DNA directly from soils. Appl Environ Microbiol. 1999;65(12):5409-5420.

18. Wu L, Li F, Deng C, Xu D, Jiang S, Xiong Y. A method for obtaining DNA from compost. Appl Microbiol Biotechnol. 2009;84(2):389-95. doi: 10.1007/s00253-009-2103-8.

19.Abu Al-Soud W, Râdström P. Capacity of nine thermostable DNA polymerases to mediate DNA amplification in the presence of PCRinhibiting samples. Appl Environ Microbiol. 1998;64(10):3748-53.

20. Weiss A, Jérôme V, Freitag R. Comparison of strategies for the isolation of PCR-compatible, genomic DNA from a municipal biogas plants. ] Chromatogr B Analyt Technol Biomed Life Sci. 2007;853(1-2):190-7.

21. Stach JE, Bathe S, Clapp JP, Burns RG. PCR-SSCP comparison of $16 \mathrm{~S}$ rDNA sequence diversity in soil DNA obtained using different isolation and purification methods. FEMS Microbiol Ecol. 2001;36(2-3):139151

22. McIlroy SJ, Porter K, Seviour RJ, Tillett D. Extracting nucleic acids from activated sludge which reflect community population diversity. Antonie Van Leeuwenhoek. 2009;96(4):593-605. doi: 10.1007/ s10482-009-9374-z.

23. YuZ, Mohn W. Bacterial diversity and community structure in an aerated lagoon revealed by ribosomal intergenic spacer analysis and 16S rDNA. Appl Environ Microbiol. 2001;67(4):1565-1574. doi 10.1128/AEM.67.4.1565-1574.2001

24. Otawa K, Asano R, Oba Y, Sasaki T, Kawamura E, Koyama F, et al Molecular analysis of ammonia-oxidizing bacteria community in intermittent aeration sequencing batch reactors used for animal waste water treatment. Environ Microbiol 2006;8(11):1985-96. DOI: 10.1111/j.1462-2920.2006.01078.x.

25. Baker CJ, Fulthorpe RR, Gilbride KA. An assessment of variability of pulp mill waste water treatment system bacterial communities using molecular methods. Water Qual Res J Can 2003;38:227-42.

26. Gilbride KA, Fulthorpe RR. A survey of the composition and diversity of bacterial populations in bleached kraft pulp-mill waste water secondary treatment systems. Can J Microbiol. 2004;50(8):633-44. DOI: $10.1139 / \mathrm{w} 04-031$.

27. Baker CJ, Fulthorpe RR, Kimberley, A. Gilbride. An assessment of variability of pulp mill waste water treatment system bacterial communities using molecular methods. Water Qual Res J Can 2003;38:227-42.

28. Gilbride KA, Frigon D, Cesnik A, Gawat J, Fulthorpe RR. Effect of chemical and physical parameters on a pulp mill biotreatment bacterial community. Water Res. 2006;40(4):775-87. DOI: 10.1016/j. watres.2005.12.007.

29. Casserly C, Erijman L. Molecular monitoring of microbial diversity in an UASB reactor. Int Biodeterior Biodegrad 2003;52(1):7-12.
30. Ingvorsen, K., B. Hjer-Pedersen, and S. E. Godtfredsen. Novel cyanide-hydrolyzing enzyme from Alcaligenes xylosoxidans subsp. denitrificans. Appl Environ Microbiol. 1991;57(6):1783-9.

31. Kim, B. S., H. M. Oh, H. J. Kang, S. S. Park, and J. S. Chun. Remarkable bacterial diversity in the tidal flat sediment as revealed by $16 \mathrm{~S}$ rDNA analysis. J. Microbiol. Biotechnol. 2004;14:205-211.

32. Clarke K, Gorley R. PRIMER v5: user manual/tutorial. Plymouth, UK: PRIMER-E. 2001.

33. Shannon CE, Weaver W. The mathematical theory of communication. Urbana, IL: University of Illinois Press. 1963.

34. Pielou EC. Ecological diversity. New York: Wiley. Polz MF, Cavanaugh CM. Bias in template-to-product. 1975.

35. Fromin N, Hamelin J, Tarnawski S, Roesti D, Jourdain Miserez K, Forestier N. Statistical analysis of denaturing gel electrophoresis finger printing patterns. Environ Microbiol. 2002;4(11):634-43.

36.ter Braak CJF, Verdonschot PFM. Canonical correspondence analysis and related multi variate methods in aquatic ecology. Aquat Sci 1995; 57(3):255-89.

37. Boon N, Windt WD, Verstraete W, Top EM. Evaluation of nested PCR-DGGE with group-specific 16S rRNA primers for the analysis of bacterial communities from different wastewater treatment plants. FEMS Microbiol Ecol. 2002;39(2):101-12. doi: 10.1111/j.15746941.2002.tb00911.x.

38. Cocolin L, Bisson LF, Mills DA. Direct profiling of the yeast dynamics in wine fermentations. FEMS Microbiol Lett. 2000;189(1):81-7.

39. YuZ, Mohn W. Bacterial diversity and community structure in an aerated lagoon revealed by ribosomal intergenic spacer analysis and 16S rDNA. Appl Environ Microbial. 2001;67:1565-74.

40. Gilbride KA, Frigon D, Cesnik A, Gawat J, Fulthorpe RR. Effect of chemical and physical parameters on a pulp mill biotreatment bacterial community. Water Res. 2006;40(4):775-87.

41. Kavanaugh RG, Randall CW. Bacterial populations in a biological nutrient removal plant. Water Sci Technol 1994;29(7):25-34.

42. Kuba T, Wachtmeister A, van Loosdrecht MCM, Heijnen JJ. Effect of nitrate on phosphorus release in biological phosphorus removal systems. Water Sci Technol 1994;30(6):263-269.

43. Davenport RJ, Curtis TP, Goodfellow M, Stainsby FM, Bingley M. Quantitative use of fluorescent in situ hybridization to examine relationships between mycolic acid-containing actinomycetes and foaming in activated sludge plants. Appl Environ Microbiol. 2000;66(3):1158-66.

44. Schramm A, Santegoeds C, Nielsen H, Ploug H, Wagner M, Pribyl M. On the occurrence of anoxic microniches, denitrification and sulfate reduction in aerated activated sludge. Appl Environ Microbiol 1999;65(9):4189-96.

45. Lemarchand K, Berthiaume F, Maynard C, Harel J, Payment P, Bayardelle P. Optimization of microbial DNA extraction and purification from raw wastewater samples for downstream pathogen detection bymicroarrays . J Microbiol Methods. 2005;63(2):115-26. DOI: 10.1016/j.mimet.2005.02.021.

46. Suzuki MT, Giovannoni SJ. Bias caused by template annealing in the amplification of mixtures of 16Sr RNA genes by PCR. Appl Environ Microbiol 1996; 62(2):625-30.

47. Tebbe CC, Vahjen W. Interference of humic acids and DNA extracted directly from soil in detection and transformation of recombinant DNA from bacteria and yeast. Appl Environ Microbiol. 1993; 59(8): $2657-2665$.

48. Limpiyakorn T, Shinohara Y, Kurisu F, Yagi O (2005) Communities of ammonia-oxidizing bacteria in activated sludge of various sewage treatment plants in Tokyo. FEMS Microbiol Ecol. 2005;54(2):205-17. 